\title{
Freedom of Language
}

\section{A Review of the Volume György Andrássy: Freedom of Language: A Universal Human Right to Be Universally Recognized ${ }^{1}$}

\author{
Noémi NAGY \\ University of Pécs, Faculty of Law \\ When one finds out something new, he will soon become a minority; \\ a minority which has only one member: himself. ${ }^{2}$
}

Anyone who has for the past two decades followed the work of György Andrássy, Professor of Law at the University of Pécs, is not unfamiliar with the notion of freedom of language. He started to develop the idea that every people has the right to a so far lesser known and recognized freedom, i.e. freedom of language. In the early 90s - and since then -, he published about a dozen studies $^{3}$ on the subject in Hungarian and English languages. However, Andrássy's book, published in 2013, is far from a mere summary: the concept of freedom of language is being justified more thoroughly than ever, discussing questions so far not raised, from a logical as well as historical perspective, while processing an enormous amount of material from among the preparatory documents of the

1 Andrássy, György: Nyelvszabadság: Egy egyetemes elismerésre váró egyetemes emberi jog. Dialóg Campus Kiadó, Budapest-Pécs, 2013.

2 Robert Fischer: Hogyan tanítsuk gyermekeinket gondolkodni? [How to Teach Our Children to Think?]. Múszaki Könyvkiadó, Budapest, 2000. p. 49. Cited by: Andrássy, György: ibid. p. 10. All translations here belong to the reviewer.

3 Among them, the following should be highlighted: Etnikai kisebbségek és emberi jogok [Ethnic Minorities and Human Rights]. Regio, 1993/2. 74-79; Etnikai kisebbségek és emberi jogok: Alkalmazható-e Rawls érvelése? [Ethinc Minorities and Human Rights: Is It Possible to Apply Rawls’ Reasoning?]. In: Erkölcs és változás (186-191). Kaposvár, 1994; Nyelvi jogok. A modern állam nyelvi jogának alapvetó kérdései, különös tekintettel Európára és az európai integrációra [Language Rights. Basic Questions of Modern States' Language Law with Special Regard to Europe and the European Integration]. Janus Pannonius Tudományegyetem Európa Központ, Pécs, 1998; Nyelvszabadság: egy elismerésre váró emberi jog [Freedom of Language: A Human Right to Be Recognized]. Jogtudományi Közlöny, Vol. LXIV. No. 11. 2009. 445-456; Freedom of Language: A Universal Human Right to Be Recognized. International Journal on Minority and Group Rights. Vol. 19. No 2. 2012. 195-232. 
Universal Declaration of Human Rights. Not only this material was unknown in the Hungarian language but the extensive international commentaries also failed to analyse the Declaration from the point of view of language rights. Andrássy's research related to the preparatory materials of the Declaration would reflect credit even on a legal historian, but for a legal scholar and philosopher it is especially commendable that he undertook such a large-scale task.

The genre of 'Freedom of Language' is basically jurisprudence and international law; however, due to its chapters related to philosophy and legal history - moreover, due to its linguistic and psychological references -, the book is indisputably multidisciplinary, in the best sense. Perhaps this somewhat explains why the author had been procrastinating to write the book for a long time, because as Head of the Department of Social Theory and Political Science of the University of Pécs he mainly taught philosophy. As a matter of fact, he discovered freedom of language in a philosophical context, via Rawls's theory of justice, ${ }^{4}$ and thus he initially tried to justify the concept by means of well-known and widely accepted philosophical arguments. Since these arguments were borrowed from the philosophy of human rights, he quickly reached the conclusion that freedom of language is a human right, too, and therefore it should be given a place on the lists of human rights. As the most important lists of human rights were established within the international law of human rights, this theoretical problem has a serious practical, legislative significance, as well (cf. p. 9).

It is indeed extraordinary, and the reviewer has countless times raised the question of how it is possible that such a self-evident freedom - the right of every people to use their own language - has not been recognized by international law, and that international legislation on minority protection, revived in the 90s, has not led one single international lawyer to realize that there has been some fundamental deficiency here. After all, the notion of freedom of language is not a brand new one: the Belgian Constitution has already recognized it since 1831, the Swiss Constitution since 1998, and, in fact, international law also recognized this freedom once: between the two world wars, under the auspices of the minority protection system of the League of Nations. Since then, the matter has somehow been forgotten, and the issue of linguistic rights has arisen almost exclusively as a minority problem. Andrássy's question - raised with an almost naive naturalness - as to why persons belonging to the linguistic majority have no language rights, is usually followed by a stunned silence - as the writer of these lines has witnessed this several times. Scholars awakening from their perplexity tend to put forward the sort of arguments such as: 1 . the fact that people belonging to the linguistic majority are entitled to these rights is self-evident, thus it would be pointless to formulate this right explicitly; 2 . for the very same reason, people belonging to the linguistic majority have never requested this; 3 . problems related to language

4 Rawls, John: Az igazságosság elmélete [Theory of Justice]. Osiris Kiadó, Budapest, 1997. 
rights usually arise in connection with persons belonging to linguistic minorities; 4. persons belonging to the linguistic majority do not need to be protected by international law because their language rights are sufficiently safeguarded in the states' domestic law. ${ }^{5}$ Andrássy gives a comprehensive answer to every objection, but here it seems to be sufficient to state that the last three arguments whether we accept them as well-founded or not - are built upon purely practical considerations; however, we are dealing with a theoretical issue of particular importance, namely an issue of human rights. Since according to the doctrine of human rights people are entitled to human rights by their own existence as human beings, by their human essence, human nature, or human dignity, the recognition of these rights cannot depend on practical considerations at all.

To the first argument, the easiest answer is that the teachings of natural law and human rights law happen to formulate the obvious, self-evident, and indisputable truths. However, treating language rights as minority rights is problematic for another reason as well - a reason to which only Andrássy has drawn the attention so far: the fact that human rights are universal rights to which all people are entitled, implies by definition that minority language rights do not fit into these rights. For this reason, international human rights law has been overwhelmed with problems of coherence - using one of the author's favourite terms: paradigm anomalies -, which can only be eliminated by recognizing the linguistic rights of persons belonging to the linguistic majority as well. (As a matter of fact, these are implicitly inherent in the institution of official language; what is the obstacle then to an explicit recognition?)

Having said that, there seems nothing left to do but justify that freedom of language is indeed a human right. In fact, legal positivists would say that the very existence of human rights must be proved first. However, this is such a huge task which the author does not undertake, not even in a four-hundred-page book, and it turns out soon that there is no need to do so anyway. Although Andrássy 'does not want to deprive himself of the advantages' (p. 29.) that the various ways of justification offer, he basically chooses a simple but great method of argumentation requiring extreme rigour and logical clarity: he derives freedom of language from the prevailing theory of human rights and the national and international law of human rights. Therefore, he does not join the debate about the existence of human rights, rather he takes recognized human rights as his starting point. He derives freedom of language in a form in which it is missing from the existing lists of human rights. 'This method of argumentation has two major advantages: on the one hand, the derivation is logically compelling at several points, on the other hand, such a derivation leads to the conclusion that the theory or legal material from which the justification starts out includes and as such implicitly acknowledges freedom of language. And this, if

$5 \quad$ For more details, see: Andrássy, György: A nyelvszabadságról és a nyelvszabadság jelentőségéről [About Freedom of Language and Its Significance]. Létünk, 2013/különszám, 7-19. 
the starting point of justification happens to be the domestic and international law of human rights, in fact means that the domestic and international law of human rights already include freedom of language, and therefore legislators only need to recognise what they already have recognised tacitly or implicitly' (p. 30).

This is the essence of Chapter IV, making up about two thirds of the book: the derivation of freedom of language from the perhaps best known and most authoritative list of human rights, i.e. the Universal Declaration of Human Rights. ${ }^{6}$ Without 'depriving the reader of the advantages' which reading the book offers, it may be revealed that as a result of an incredibly thorough legal historical investigation and infallible logical deductions Andrássy proves that the Declaration is certainly incomplete and inadequate from both a historical and a logical point of view. 'First of all, because the drafters of the Declaration left a few questions related to linguistic human rights unresolved and, secondly, because the preparatory works of the Declaration actually included the answers to these questions left pending' (p. 355).

In the final chapter of the book, the author himself proposes a draft to supplement the Declaration with: the first point of this hypothetical new article refers to freedom of language in private life, while the second point concerns the use of own language as an official language. Although Andrássy's previous works also included similar draft supplements, in the current text, every single word is of significance since the careful choice of the terms used in the draft supplement - which can be considered as the essence of the book - was preceded by a theoretical discussion of several hundreds of pages.

To conclude, 'Freedom of Language: A Universal Human Right to be Universally Recognised' is a unique book filling a serious theoretical niche. The volume is a ripe fruit of György Andrássy's two-decade research on the subject, his extensive knowledge of philosophy and other disciplines, his common sense and logical acumen. The book is a must read for not only international jurists and scholars interested in human rights but - because of its multidisciplinary nature - it is strongly recommended for professionals of other areas of law, moreover, for linguists as well as philosophers. The reviewer expresses her hope that the message of the book will reach political decision-makers, what could lead to a new, perhaps fairer and more consistent approach towards the language issue: the recognition of freedom of language could provide just as substantive indications for the states' linguistic legislation as, for example, freedom of religion did for the legislation related to religions and churches. ${ }^{7}$

6 It is no secret of the author's that 'Freedom of Language' was planned to contain two volumes. In the second volume, freedom of language will be derived, among others, from the International Covenant on Civil and Political Rights.

7 Cf. Andrássy, György: A nyelvszabadságról és a nyelvszabadság jelentőségéről [About Freedom of Language and Its Significance]. Létünk, 2013/különszám, 7-19. 